\title{
Alcohol and brief intervention for trauma victims
}

\section{Consumo de álcool e intervenção breve em vítimas de trauma}

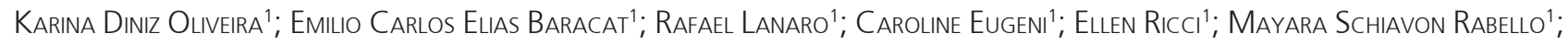 \\ Juliana Perpetuo de Souza'; Vitoria Carneiro Gimenes'; Renata Cruz Soares de Azevedo'; Gustavo Pereira Fraga'
}

\section{A B S T R A C T}

\begin{abstract}
Objective: to describe the causes and severities of trauma in patients who met the criteria for alcohol abuse or dependence according to Mini International Neuropsychiatric Interview, and to display the pattern of alcohol consumption and subsequent changes one year after trauma. Methods: a transversal and longitudinal quantitative study carried out between November 2012 and September 2013 in the ED. Medical and nursing students collected blood samples, applied the J section of the Mini International Neuropsychiatric Interview (MINI) and submitted alcohol abusers and dependents to BI. One year after admission, patients were contacted and asked about their patterns of alcohol use and their reasons for any changes. Results: from a sample of 507 patients admitted to the ED for trauma, 348 responded to MINI, 90 (25.9\%) being abusers and 36 (10.3\%) dependent on alcohol. Among the abusers, the most frequent cause of injury was motorcycle accident (35.6\%) and among the dependents it was predominantly interpersonal violence (22.2\%). Positive blood samples for alcohol were identified in $31.7 \%$ of the abusers and $53.1 \%$ of the dependents. One year after trauma, 66 abusers and 31 dependents were contacted, and it was ascertained that $36.4 \%$ of the abusers and $19.4 \%$ of the dependents had decreased alcohol consumption. The main reported reason for the reduction was the experienced trauma. Conclusion: the motorcycle accident was the most common cause of injury. The detection of problematic alcohol use and implementation of $\mathrm{BI}$ are important strategies in the ED, however for alcohol abusers and dependents, BI was not the most reported reason for any changes in patterns of alcohol use.
\end{abstract}

Key words: Alcoholism, Wounds and Injuries. Emergencies. Alcohol-Related Disorders.

\section{INTRODUCTION}

A mong the central nervous system depressants, alcohol is the psychoactive substance (PAS) most consumed around the world. There are around two billion people worldwide who consume alcohol regularly ${ }^{1}$. According to data from the World Health Organization (WHO), 3.2\% of deaths worldwide are related to alcohol ${ }^{2}$. Nevertheless, the extent and magnitude of the role of alcohol in fatal and non-fatal injuries around the world is still not fully understood ${ }^{2}$.

The early effects of alcohol are attention impairment, poor perception and poor critical judgment of reality, which can all increase the risk of traffic accidents ${ }^{3}$. Moreover, alcohol can be a catalyst in developing aggressive behavior4.

In Brazil, trauma is a public health problem. It is the leading cause of death in the age group 1-39 years ${ }^{5}$. Currently, the most common causes of trauma in Brazil, and in the world, are acts of violence (homicides) and traffic accidents ${ }^{5,6}$.

A review found that $10-18 \%$ of cases in the Emergency Department (ED) have some relation to alcohol?
Nevertheless, the use of PAS is still little detected, which limits the development of prevention strategies and appropriate approaches to problematic alcohol users ${ }^{8}$.

The ED is often the first health service sought by alcohol abusers or alcoholics, and it should be seen as a strategic location for patient awareness regarding the harm caused by alcohol abuse, since the relationship between the use of PAS and the damage it causes is close, in terms of time ${ }^{9-11}$. A brief intervention (BI) is a form of assistance by way of a short interview, aiming to motivate a behavior change, alleviate any problems related to alcohol use, and to help the patient take decisions, such as looking for treatment or reducing use $\mathrm{e}^{8,10}$. The advantages of a Bl include low cost and ease of application since it is rapid (lasting from 10 to 45 minutes) and can be included in usual consulting appointments. Moreover, it can be performed by any trained health professional. Surveys have shown its effectiveness in the treatment of alcohol abusers, however there are limitations in its effectiveness for people with alcohol dependence ${ }^{8-11}$.

The "Mini International Neuropsychiatric Interview" (M.I.N.I.) ${ }^{12}$ is an elaborated standardized interview based on diagnostic criteria from the fourth edition

1. Faculdade de Ciências Médicas, Universidade Estadual de Campinas (Unicamp), Campinas, SP, Brasil. 
of the "Diagnostic and Statistical Manual of Mental Disorders" (DSM) ${ }^{13}$ and the "International Classification of Diseases" (ICD) ${ }^{14}$. Section J identifies criteria for alcohol abuse e dependency.

The objectives of the study were to describe the causes and severities of trauma in patients who met the criteria for alcohol abuse or dependence according to Mini International Neuropsychiatric Interview, and to display the pattern of alcohol consumption and subsequent changes one year after trauma.

\section{METHODS}

This is a quantitative, longitudinal, cross-sectional study, carried out in the ED of "Hospital de Clínicas" at the Universidade Estadual de Campinas (Unicamp), in the city of Campinas, Brazil. Data were collected between November 2012 and September 2013. Patients who arrived at the ED as a result of trauma were invited to participate in the study, signing an informed consent form. This study was approved by the Comitê de Ética em Pesquisa of Unicamp, with document number 185.108.

The inclusion criteria were: patients older than 18 years, admitted to the ED as a result of trauma, with primary care conducted by the Trauma Surgery Faculty of Unicamp, and length of stay in the ED or in the hospital for more than six hours. For the purposes of this study, trauma was defined as: "any damage to the human body which is caused by sudden exposure to physical agents such as mechanical energy, heat, electricity, chemicals or radiation that interact with the body to a degree that exceeds the limits of human tolerance"15,16. Alcohol abuse and dependence were diagnosed according to the M.I.N.I. criteria $^{12}$. Alcohol abuse was diagnosed when an individual responded positively to three of the questions from the relevant M.I.N.I. section. Data collection was carried out at three times: early in the morning to collect the data of patients admitted during the night, at lunchtime for those admitted during the morning, and in the early evening for those admitted during the afternoon.
The importance of the brevity of care arose from the need for blood to be taken immediately after the trauma event. Blood alcohol levels decrease with time and become undetectable within six hours, by the methods available in this study. The inclusion of patients referred from other hospitals, who had already received first aid, would result in an increased number of negative samples, due to the metabolization of alcohol by the body, causing a high rate of false negatives.

After acceptance and signature, the patient was subjected to a semi-structured interview and section $\mathrm{J}$ of M.I.N.I., which evaluates alcohol abuse and dependence $(\text { Table } 1)^{12}$. The subjects who met the criteria for PAS abuse (three or more positive responses to the questions listed in Table 1) or PAS dependence (three or more positive responses to the questions listed in Table 2), according to M.I.N.I., underwent BI.

The severity of the trauma was determined using the "Injury Severity Score" index (ISS) 17,18. The subjects whose ISS values were higher than 16 suffered traumas considered more severe.

A blood sample was taken in a dry tube. The technique of choice for treatment of the samples was a "headspace" technique, which consists of heating and evaporating a sample (in an oven at $70^{\circ} \mathrm{C}$ for 30 minutes) within a glass vial. The conditioned sample is later injected into a gas chromatography system with flame ionization detection.

Patients who presented diagnostic criteria for alcohol abuse or dependence were submitted to BI at the hospital shortly after the interview and questionnaire. Follow-up was conducted one year after the trauma, by three professionals specialized in Mental Health, who asked, via telephone, about the patterns of alcohol use as well as the reasons for any changes in them.

Association between categorical variables was based on the chi-square test. The significance level adopted for the statistical tests was $5 \%$ and the confidence interval for "Relative Risk", 95\%.

Table 1 - Criteria for alcohol abuse according to M.I.N.I.

\section{During the last 12 months:}

1. Have you become drunk or have a hangover several times, when you had things to do at work/school or at home? Has this caused you problems?

2. Have you ever been under the influence of alcohol in situations where it was physically risky, such as driving, using a machine or a dangerous instrument?

3. Have you had legal problems such as a summons, conviction or arrest because you had been drinking?

4. Have you continued to drink even though you knew that drinking caused problems with your family or others?

Source: Sheehan DV, Lecrubier Y, Sheehan KH, Amorim P, Janavs J, Weiller E, et al. The Mini-International Neuropsychiatric Interview (M.I.N.I.): the development and validation of a structured diagnostic psychiatric interview for DSM-IV and ICD-10. J Clin Psychiatry. 1998;59 Suppl 20:2233 . 
Table 2 - Criteria for alcohol dependency according to M.I.N.I.

1. Have you drunk, in less than three hours, more than five bottles of beer, or a bottle of wine, or three of a strong alcoholic beverage (pinga, caipirinha, brandy, vodka, whiskey, etc.)?

\section{During the last 12 months:}

2. Have you found that you have needed increasing amounts of alcohol to achieve the same effect?

3. When you drank less, did your hands shake, did you sweat or feel agitated?

4. Have you ever drunk a dose to avoid these problems or to prevent a hangover?

5. When starting to drink, did you often drink more than intended?

6. Have you tried but failed to reduce your alcohol consumption or to stop drinking?

7. During the days that you drank, did you spend much time looking for drink, drinking or recovering from the effects of alcohol?

8. Have you reduced your activities (leisure, work, daily tasks) or spent less time with others because of drink?

9. Have you continued to drink even though it caused you health problems or psychological problems?

Source: Sheehan DV, Lecrubier Y, Sheehan KH, Amorim P, Janavs J, Weiller E, et al. The Mini-International Neuropsychiatric Interview (M.I.N.I.): the development and validation of a structured diagnostic psychiatric interview for DSM-IV and ICD-10. J Clin Psychiatry. 1998;59 Suppl 20:2233.

\section{RESULTS}

All subjects, those excluded and those who answered the questionnaire are shown in figure 1.

Of the 453 subjects included in the study, 42 died and 63 remained unconscious or suffered injuries as a result of the trauma which prevented them from answering the questionnaire. The variables "gender", "education", "occupation" and "marital status" of alcohol abusers and dependents are shown in table 3. Considering the history of alcohol use, $65.6 \%$ of the dependents and $63.7 \%$ of the abusers reported initial alcohol use before the age of 18. Causes of trauma in subjects with alcohol abuse or dependence are described in Table 4. The values of ISS were higher than 16 in $16.9 \%$ of the abusers and $36.1 \%$ of the dependents. The samples were positive for alcohol in $31.7 \%$ of the abusers and $53.1 \%$ of the dependents.

During the follow-up, one year after admission, 66 alcohol abusers and 31 dependents were contacted.

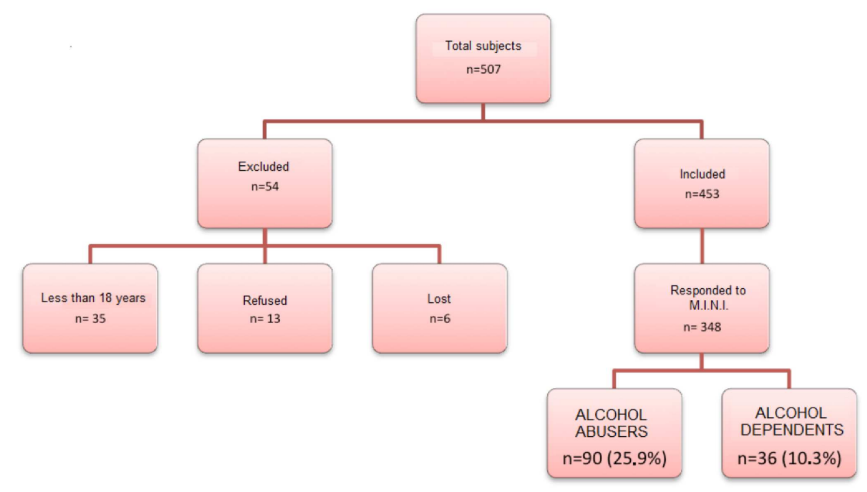

Figure 1 - Included subjects and problematic users of alcohol admitted for trauma.

Source: Unidade de Emergência Referenciada do Hospital de Clínicas da Unicamp.
Among the abusers, 40 (60.6\%) had maintained their patterns of alcohol use, 20 (30.3\%) had reduced them and six $(9.1 \%)$ had discontinued alcohol use. Among the dependents, $25(80.6 \%)$ had maintained their patterns of use, two (6.5\%) had reduced them and four (12.9\%) had discontinued alcohol use. The reasons reported for the discontinuations or reductions were: trauma sequelae (8 abusers and 2 dependents), the trauma event (three abusers and two dependents), the brief intervention (four abusers and one dependent). Eleven other patients (then abusers and one dependent) reported other reasons for discontinuation/reduction. None of the abusers or dependents, who responded to the $\mathrm{BI}$, died.

\section{DISCUSSION}

The study focused on a sample of patients who were alcohol abusers and dependents (alcoholics) admitted to the emergency department due to trauma. The sociodemographic data indicated that most were young men with reasonable schooling, compared with the national average, and in active employment. It is important to note that the characteristics of those who seek emergency assistance are different from those of the general population, due to peculiarities such as morbidity, social status and the use of PAS which are specific to ED patients and therefore should not be generalized ${ }^{19}$.

The sociodemographic characteristics of the sample are similar to those found in other studies which address trauma victims: men, young, actively employed ${ }^{19-21}$. If we consider the pattern of PAS use however, the employment situation differs from data within the general population, since alcohol abusers and dependents are mostly not in active employment. Compared to other health problems in Brazil, alcoholism is responsible for generating three times more sick leave, increasing the chances of work accidents fivefold, 
Table 3 - Correlation of sociodemographic variables in patients who met criteria for alcohol abuse or dependence.

\begin{tabular}{|c|c|c|c|c|c|c|}
\hline \multirow{2}{*}{$\begin{array}{l}\text { Variable } \\
\text { Gender }\end{array}$} & \multicolumn{2}{|c|}{$\begin{array}{l}\text { Abusers } \\
N(\%)\end{array}$} & \multirow[t]{2}{*}{$p$-value* } & \multicolumn{2}{|c|}{$\begin{array}{c}\text { Dependents } \\
\mathrm{N}(\%)\end{array}$} & \multirow[t]{2}{*}{$p$-value* } \\
\hline & & & & & & \\
\hline Masculine & 80 & (88.9) & 0.283 & 35 & $(97.2)$ & 0.035 \\
\hline Feminine & 10 & (11.1) & & 1 & $(2.8)$ & \\
\hline \multicolumn{7}{|l|}{ Education } \\
\hline$<8$ years & 46 & $(47.7)$ & 0.203 & 21 & $(60.1)$ & 0.203 \\
\hline$>8$ years & 44 & (52.3) & & 15 & (39.9) & \\
\hline \multicolumn{7}{|l|}{ Occupational Status } \\
\hline Unemployed & 9 & $(10.2)$ & 0.092 & 4 & (11.1) & $<0.001$ \\
\hline Employed & 78 & (86.7) & & 30 & (83.4) & \\
\hline Not applicable & 3 & (3.1) & & 2 & $(5.5)$ & \\
\hline \multicolumn{7}{|l|}{ Marital Status } \\
\hline Steady partner & 28 & (31.4) & 0.038 & 15 & $(41.6)$ & 0.007 \\
\hline No steady partner & 62 & $(68.6)$ & & 21 & $(58.4)$ & \\
\hline
\end{tabular}

Source: Unidade de Emergência Referenciada do Hospital de Clínicas da Unicamp.

* Chi-square test

Table 4 - Causes of trauma in subjects with alcohol abuse or dependence.

\begin{tabular}{|c|c|c|}
\hline Cause of trauma & $\begin{array}{c}\text { Abusers } \\
\mathrm{N}(\%)\end{array}$ & $\begin{array}{c}\text { Dependents } \\
\mathrm{N}(\%)\end{array}$ \\
\hline Motorcycle accident & $32(35.6)$ & $5(13.9)$ \\
\hline Car accident & $13(14.4)$ & $5(13.9)$ \\
\hline Running over & $5 \quad(5.6)$ & $3 \quad(8.3)$ \\
\hline Fall from a height & $7 \quad(7.8)$ & $3 \quad(8.3)$ \\
\hline Beating & $6 \quad(6.7)$ & $8(22.2)$ \\
\hline Fall & $3 \quad(3.3)$ & $2 \quad(5.6)$ \\
\hline Wound from firearm projectile & $8 \quad(8.9)$ & $3 \quad(8.3)$ \\
\hline Knife wound & $9(10.0)$ & $3 \quad(8.3)$ \\
\hline Others & $6 \quad(6.7)$ & $4(11.1)$ \\
\hline Losses & $1 \quad(1.1)$ & - \\
\hline TOTAL & $90 \quad(100)$ & $36(100)$ \\
\hline
\end{tabular}

Source: Unidade de Emergência Referenciada do Hospital de Clínicas da Unicamp.

increasing hospital visits eightfold and causing families to use medical and social assistance three times as much ${ }^{22}$.

A positive blood alcohol level is indicative of recent alcohol use. In this study, approximately $30 \%$ of those who reported abuse, and $53 \%$ of those who met the criteria for addiction, gave positive samples, indicating alcohol use within six hours prior to admission. Several international studies show that alcohol intoxication is associated with admission to the ED for trauma, and they describe proportions of up to $50 \%$ of patients who are intoxicated at the time of trauma ${ }^{23,24}$.

A study published by WHO showed that approximately $47 \%$ of trauma victims had positive blood alcohol levels, and that $40 \%$ of trauma patients with negative levels presented criteria for problematic use of $\mathrm{PAS}^{2}$. Thus, a negative sample is not sufficient to exclude problems related to alcohol use. The gold standard PAS usage detection is the combination of clinical history and laboratory measurement of PAS $^{3}$.

Most addicts and abusers reported initial alcohol use during adolescence. In addition to being the period in which PAS experimentation mostly occurs, starting during adolescence can increase the chances of an individual developing a more severe habit in adult life ${ }^{25}$.

Among the dependents who have experienced trauma, a significant portion were the victims of acts of violence (mainly beatings), with $36.1 \%$ having ISS scores greater than 16, that is, they suffered traumas considered more severe. Alcohol use is related to violent acts as much for victims as for aggressors. A study, which examined victims of violent deaths, found positive blood alcohol levels in $70 \%$ of $\operatorname{casos}^{26}$. 
Alcohol poisoning causes a loss of ability to concentrate for several hours after ingestion, as well as a loss of psychomotor skills and an increase in impulsivity ${ }^{27,28}$. These reactions can catalyze personality traits, increasing or causing aggressive tendencies, which can culminate in illegal acts, which can lead to involvement in violent acts ${ }^{29}$. Offenders intoxicated by alcohol commit more than half of crimes $^{30}$. Among abusers of alcohol, their most common cause of injury is from traffic accidents (56.2\%).

Alcohol use is more prevalent among drivers who are involved in traffic accidents ${ }^{31}$. Drunk drivers have a higher frequency of involvement in accidents than those who are sober. Alcohol use slows reflexes and impairs motor coordination, increasing the chance of collision. In addition, drivers who use alcohol use seat belts less often drive at higher speeds and have a greater risk of distraction ${ }^{32}$. In a Brazilian survey on alcohol use, $21.6 \%$ of adults admitted that they had already driven drunk at least once in their lives ${ }^{21}$.

At the time of the follow-up interview, one year after admission to the emergency department, it was found that a significant portion of abusers $(36.4 \%$ ) had discontinued or decreased alcohol use. Few, however, referred to the $\mathrm{Bl}$ as the determining factor in discontinuing or reducing alcohol consumption. The consequences of trauma were cited as the main reason for change in PAS usage. Among abusers, the fact that they had suffered an injury, directly due to PAS usage, was considered sufficient to review their consumption. Although all were subjected to $\mathrm{BI}$, this was the least cited reason among those who either stopped or reduced their alcohol consumption.

This can be explained by a lack of understanding of the patient's compliance with the role of $\mathrm{Bl}$, since it was carried out by graduate students with less experience in chemical dependency treatment, or by the greater impact made the trauma event itself.

Therefore, it is important that the training of emergency department professionals is well executed, so that the treatment of problematic users of PAS is appropriate and effective.
Among the dependents, the portion which reduced or stopped consumption, for whatever reason, was much lower. When the severity of use is greater, there is a need for other handling mechanisms in order to reduce usage or stop. This finding is consistent with other studies, carried out in the ED, which found little effectiveness of $\mathrm{BI}$ one year after its completion ${ }^{8}$. One of the reasons for this finding may be the need for continuity of user monitoring, by specialized services or with skilled professionals, who can support the patient, preserving motivation and preventing or dealing with relapses. Without regular monitoring, it is more difficult to maintain abstinence or reduce usage.

This study shows high rates of blood alcohol concentration and disorders related to alcohol use (abuse and dependence) among trauma victims. Following up after one year, there was a general reduction of alcohol consumption in one third of abusers and one fifth of dependents. Considering these data, the importance of preventative strategies, which address the association between use of alcohol and trauma, is reinforced. In addition, the treatment of trauma related to alcohol use can provide a window of opportunity in reducing the risky use of alcohol and consequently reducing morbidity and mortality within this population.

Considering the existing association between alcohol consumption and the occurrence of trauma, it is necessary to identify the presence of PAS use in trauma patients. Knowledge of the profile of these patients, and a better understanding of the determinants of PAS use, before and after the event, are useful tools in facilitating a more appropriate approach in the ED, and is the best strategy for intervention and prevention.

In conclusion, the motorcycle accident was the most common cause of injury, and among alcoholic abusers dependents, there was a reduction in the consumption of alcohol after the trauma, however the BI was not the most reported reason for the change in habit.

\title{
R E S U M O
}

\begin{abstract}
Objetivo: avaliar os mecanismos e a gravidade do trauma em pacientes que preenchessem critérios para abuso ou dependência de álcool de acordo com o Mini International Neuropsychiatric Interview e apresentar o padrão de consumo de álcool e as mudanças um ano após o trauma. Métodos: estudo quantitativo transversal e longitudinal realizado de novembro de 2012 a setembro de 2013 em Unidade de Emergência. O paciente era submetido a uma entrevista semiestruturada que avalia abuso e dependência de álcool. Os pacientes abusadores e dependentes de álcool foram submetidos à intervenção breve. Um ano após a admissão os pacientes foram contatados e questionados acerca do padrão de uso e as razões de eventuais mudanças. Resultados: de uma amostra de 507 pacientes admitidos na UE por trauma, 348 responderam ao MINI, sendo 25,9\% abusadores e 10,3\% dependentes de álcool. Entre os abusadores o mecanismo de trauma mais frequente foi o acidente de motocicleta $(35,6 \%)$ e nos dependentes houve predomínio de espancamento (22,2\%). Amostras de sangue positivas para álcool foram identificadas em 31,7\% dos abusadores e 53,1\% dos dependentes. Um ano após o trauma, 66 abusadores e 31 dependentes foram contatados, constatando-se que 36,4\% dos abusadores e 19,4\% dos dependentes diminuíram o padrão de consumo de álcool. A principal razão relatada de redução foi o trauma. Conclusão: o acidente de motocicleta foi o mecanismo de trauma mais frequente e entre os abusadores e dependentes de álcool houve redução do consumo de álcool após o trauma, porém a IB não foi a razão mais relatada para a mudança do hábito.
\end{abstract}

Descritores: Alcoolismo. Ferimentos e Lesões. Emergências. Transtornos Relacionados ao Uso de Álcool. 


\section{REFERENCES}

1. United Nations Office on Drugs and Crime - UNODC. World Drug Report: 2008. New York: United Nations; 2008.

2. Word Health Organization. Alcohol and injury in Emergency Departments: Summary of the report from the WHO Collaborative Study on Alcohol and Injuries. Geneve: Word Health Organization; 2007.

3. Cremonte $M$, Cherpitel CJ. Alcohol intake and risk of injury. Medicina. 2014;74(4):287-92.

4. Hankin A, Wei S, Foreman J, Houry D. Screening for violence risk factors identifies young adults at risk for return emergency department visit for injury. West J Emerg Med. 2014;15(5):60914.

5. Brasil. Ministério da Saúde. Indicadores de mortalidade. Rede Interagencial de Informações para a Saúde - RIPSA. Indicadores básicos para a saúde no Brasil: conceitos e aplicações [Internet]. Brasília (DF): Organização Pan-Americana da Saúde; 2008.

6. Mathers $C D$, Loncar $D$. Projections of global mortality and burden of disease from 2002 to 2030. PLoS Med. 2006:3(11):e442.

7. Cherpitel CJ, Bond J, Ye Y, Borges G, Macdonald S, Giesbrecht N. A cross-national meta-analysis of alcohol and injury: data from the Emergency Room Collaborative Alcohol Analysis Project (ERCAAP). Addiction. 2003;98(9):1277-86

8. D'Onofrio G, Pantalon MV, Degutis LC, Fiellin DA, Busch SH, Chawarski MC, et al. Brief intervention for hazardous and harmful drinkers in the emergency department. Ann Emerg Med. 2008;51(6):742-50.e2.

9. Cunningham RM, Bernstein SL, Walton M, Broderick K, Vaca FE, Woolard R, et al. Alcohol, tobacco, and other drugs: future directions for screening and intervention in the emergency department. Acad Emerg Med. 2009;16(11):1078-88.

10. Segatto ML, Pinsky I, Laranjeira R, Rezende FF, Vilela TR. Triagem e intervenção breve em pacientes alcoolizados atendidos na emergência: perspectivas e desafios. Cad Saúde Pública. 2007;23(8):1753-62.

11. Diestelkamp S, Arnaud N, Sack PM, Wartberg L, Daubmann A, Thomasius R. Brief motivational intervention for adolescents treated in emergency departments for acute alcohol intoxication - a randomized-controlled trial. BMC Emerg Med. 2014;14:13.

12. Sheehan DV, Lecrubier $Y$, Sheehan KH, Amorim $P$, Janavs J, Weiller E, et al. The Mini-International Neuropsychiatric Interview (M.I.N.I.): the development and validation of a structured diagnostic psychiatric interview for DSM-IV and ICD-10. J Clin Psychiatry. 1998;59 Suppl 20:22-33.

13. American Psychiatric Association. Diagnostic and statistical manual of mental disorders. 4th ed. Washington (DC): American Psychiatric Association; 1994.

14. Organização Mundial de Saúde. Manual de classificação estatística internacional de doenças e problemas relacionados à saúde. São Paulo: Centro da OMS para classificação de doenças em português - USP; 1995

15. Mattox K, Feliciano DV, Moore EE, editors. Trauma. 4th ed. New York: MacGraw Hill; 2005.

16. Baker SP, O'Neill B, Haddon W Jr, Long WB. The injury severity score: a method for describing patients with multiple injuries and evaluating emergency care. J Trauma. 1974;14(3):187-96.

17. Zerhouni $O$, Bègue L, Brousse G, Carpentier F, Dematteis $M$, Pennel $\mathrm{L}$, et al. Alcohol and violence in the emergency room: a review and perspectives from psychological and social sciences. Int J Environ Res Public Health. 2013;10(10):4584-606.
18. Santos AMR, Moura MEB, Nunes BMVT, Leal CFS, Teles JBM Perfil das vítimas de trauma por acidente de moto atendidas em um serviço público de emergência. Cad Saúde Pública. 2008:24(8):1927-38.

19. Gazal-Carvalho C, Carlini-Cotrim B, Silva OA, Sauaia N. Prevalência de alcoolemia em vítimas de causas externas admitidas em centro urbano de atenção ao trauma. Rev Saúde Pública. 2002;36(1):4754

20. Moraes E, Campos GM, Figlie NB, Laranjeira RR, Ferraz MB. Conceitos introdutórios de economia da saúde e o impacto social do abuso de álcool. Rev Bras Psiquiatr. 2006:28(4):321-5.

21. Gentilello LM, Ebel BE, Wickizer TM, Salkever DS, Rivara FP. Alcohol interventions for trauma patients treated in emergency departments and hospitals: a cost benefit analysis. Ann Surg. 2005;241(4):541-50.

22. Madras B, Compton WM, Avula D, Stegbauer T, Stein JB, Clark HW. Screeening, brief interventions, referral to treatment (SBIRT) for illicit drug and alcohol use at multiple healthcare sites: comparison at intake and 6 months later. Drug Alcohol Depend. 2009;99(1-3):280-95.

23. Laranjeira R, Madruga CS, Pinsky I, Mitsushiro S, Caetano R. II Brazilian National Alcohol and Drugs Survey. UNIAD: Unidade de Pesquisas em Álcool e Drogas.São Paulo: Universidade Federal de São Paulo (UNIFESP); 2012.

24. Duarte PCAV, Carlini-Cotrim B. Álcool e violência: estudo dos processos de homicídio julgados nos Tribunais do Júri de Curitiba, PR entre 1995 e 1998. J Bras Dep Quim. 2000;1(1):17-25.

25. Dolan SL, Bechara A, Nathan PE. Executive dysfunction as a risk marker for substance abuse: the role of impulsive personality traits. Behav Sci Law. 2008;26(6):799-822.

26. Poldrugo F. Alcohol and criminal behavior. Alcohol Alcohol. 1998;33(1):12-5.

27. Prat $G$, Adan $A$, Pérez-Pàlmies $M$, Sànchez-Turet $M$. Neurocognitive effects of alcohol hangover. Addict Behav. 2008;33(1):15-23.

28. Challub M, Telles LEB. Álcool, drogas e crime. Rev Bras Psiquiatr. 2006;28(Suppl 2):s69-s73

29. Field CA, Claassen CA, O'Keefe G. Association of alcohol use and other high-risk behaviors among trauma patients. J Trauma. 2001;50(1):13-9.

30. Shyhalla K. Alcohol involvement and other risky driver behaviors: effects on crash initiation and crash severity. Traffic Inj Prev. 2014;15(4):325-34.

31. Legrand SA, Silverans $P$, de Paepe $P$, Buylaert W, Verstraete AG. Presence of psychoactive substances in injured Belgian drivers. Traffic Inj Prev. 2013;14(5):461-8.

32. Finney JW, Moos RH. Matching patients with treatment: conceptua and methodological issues. J Stud Alcohol. 1986;47(2):122-34.

Received on 03/02/2015

Accepted for publication 10/04/2015

Conflict of interest: none.

Source of funding: Programa de Educação pelo Trabalho para a Saúde (PET-Saúde), do Programa Nacional de Reorientação da Formação (Pró-Saúde), da Secretaria de Gestão do Trabalho e da Educação na Saúde (SGTES), do Ministério da Saúde.

\section{Address for correspondence:}

Karina Diniz Oliveira

E-mail: Karina.dinizoliveira@gmail.com 